\title{
PEMBENTUKAN BUDAYA PELAYANAN PRIMA PADA KADER KESEHATAN DI KELURAHAN JABUNGAN BANYUMANIK KOTA SEMARANG
}

\author{
Sri Lestari ${ }^{11}$, Adhani Windari ${ }^{1)}$, Rizal Ginanjar'1), Eiska Rohmania Zein ${ }^{1)}$, \\ Meilinda Asrining Hapsari ${ }^{1}$, Citra Tifana ${ }^{1)}$ \\ 1)Jurusan Rekam Medis dan Informasi Kesehatan, Politeknik Kesehatan Kemenkes Semarang, Semarang, \\ Jawa Tengah, Indonesia \\ Corresponding author : Sri Lestari \\ E-mail : kids.lestari@gmail.com
}

Diterima 18 November 2021, Direvisi 08 Desember 2021, Disetujui 08 Desember 2021

\begin{abstract}
ABSTRAK
Kader kesehatan desa merupakan warga yang tinggal di wilayah kerja kader yang bekerja secara sukarela sebagai penggerak program kesehatan. Menjadi kader kesehatan desa tentu banyak tantangannya, seperti tidak memiliki pengetahuan dasar pelayanan terhadap masyarakat, direndahkan ataupun dianggap galak. Berdasarkan data di lapangan menunjukkan bahwa pengetahuan dan keterampilan kader dalam melaksanakan tugas masih jauh dari harapan. Hal ini dillihat dari pelaksanaan kegiatan posyandu yang monoton dan tidak berkembang yang nantinya akan berdampak terhadap pelaksanaan program desa siaga. Kegiatan pengabdian masyarakat ini terdiri dari beberapa tahap meliputi tahap perencanaan, pelaksanaan dan evaluasi. Pembentukan pelayanan budaya prima pada kader kesehatan merupakan kegiatan untuk mempersiapkan kader kesehatan agar mau dan mampu berperan serta dalam mengembangkan program kesehatan di desanya. Kegiatan pengabmas dengan sasaran kader kesehatan di Kelurahan Jabungan menggunakan metode pelatihan yang diselenggarakan secara daring dengan memberikan dasar pengetahuan tentang pelayanan prima kepada masyarakat. Menyiasati keadaan wilayah Kota Semarang yang masih dilanda pandemi Covid, maka pengabmas dilaksanakan secara virtual menggunakan media zoom meeting. Luaran pengabdian masyarakat tentang Pembentukan Budaya Pelayanan Prima pada Kader Kesehatan di Kelurahan Jabungan Banyumanik Kota Semarang berupa peningkatan pemahaman dan keterampilan masyarakat, sertifikat dan Buku Saku Pelayanan Prima Bagi Kader Kesehatan Desa serta hasil pengabmas dijurnalkan di jurnal pengabdian masyarakat.
\end{abstract}

Kata kunci: pelayanan prima; kader kesehatan.

\begin{abstract}
Village health cadres are residents who live in the working area of cadres and work voluntarily as drivers of health programs. There are many challenges for village health cadres, such as not having basic knowledge of community services, being humiliated, or being considered fierce. Based on field data, shows that the knowledge and skills of cadres in carrying out their duties are still far from expectations. It can be seen from the monotonous and undeveloped implementation of posyandu activities which will have an impact on the implementation of the standby village program. This community service activity consists of several phases including the planning, implementation, and evaluation phase. The establishment of excellent cultural services for health cadres is an activity to prepare health cadres to be willing and able to participate in developing health programs in their villages. Community service activities targeting health cadres in Jabungan Village use online training methods by providing a basic knowledge of excellent service to the community. Dealing with the condition of the Semarang City which is still hit by the Covid pandemic, the community service is carried out virtually using zoom meeting. Outcomes of community service regarding the Formation of Culture of Excellent Service for Health Cadres in Jabungan Village Banyumanik, Semarang City in the form of increasing community understanding and skills, certificates, and Excellent Service Pocket Books for Village Health Cadres and community service results are journalized in community service journals.
\end{abstract}

Keywords: excellent service; health cardres. 


\section{PENDAHULUAN}

Program pengabdian kepada masyarakat adalah program yang berorientasi kepada permasalahan yang dihadapi oleh masyarakat berdasarkan pengamatan tiap disiplin ilmu terhadap perkembangan bidang kesehatan. Tujuan dilakukannya pengabdian kepada masyarakat adalah menerapkan teoriteori keilmuan di bidang kesehatan untuk mengatasi masalah yang terjadi di lapangan sehingga dapat memberi manfaat pada masyarakat, berpartisipasi aktif dalam proses pembangunan kesehatan, meningkatkan pemberdayaan masyarakat dalam bidang kesehatan, meningkatkan kemampuan masyarakat akademik (dosen dan mahasiswa) dalam menerapkan teori-teori keilmuan baik secara mandiri maupun kelompok dan membantu mengatasi permasalahan yang dihadapi pemerintah maupun masyarakat dengan metode ilmiah secara praktis. Hal ini ditujukan untuk menciptakan perilaku masyarakat untuk hidup sehat (Kemenkes, 2014).

Kesehatan merupakan hak asasi dan sekaligus sebagai investasi, sehingga perlu diupayakan, diperjuangkan dan ditingkatkan oleh setiap individu dan oleh seluruh komponen bangsa agar masyarakat dapat menikmati hidup sehat serta mewujudkan derajat kesehatan masyarakat yang optimal. Hal ini perlu dilakukan karena kesehatan bukanlah tanggung jawab pemerintah saja, namun merupakan tanggung jawab bersama antara pemerintah, masyarakat dan pihak swasta (Dwiyanto, 2005). Sumber daya manusia yang sehat dan berkualitas merupakan modal utama atau investasi dalam pembangunan kesehatan.

Pelayanan kesehatan perorangan secara paripurna tersebut dapat dilaksanakan dengan baik apabila dilaksanakan secara prima (Lukman, 2000). Pelayanan prima adalah suatu pola layanan terbaik dalam manajemen modern yang mengutamakan kepedulian terhadap pelanggan. Pelanggan rumah sakit pada umumnya adalah orang yang membutuhkan pelayanan kesehatan. Membutuhkan pelayanan kesehatan maknanya orang tersebut/pasien dalam keadaan terganggu kesehatannya. Gangguan kesehatan yang dialami seseorang seringkali membutuhkan pelayanan yang lebih dari orang yang sehat (Rumah Sakit Umum dr. Moedjito Dwidjosiswojo, 2020).

Pelayanan prima atau biasa disebut dengan excellent service adalah melakukan pelayanan sebaik mungkin kepada para pelanggan, sehingga pelanggan merasa puas (Barata, 2003). Pelayanan prima tidak hanya dilakukan di rumah sakit, puskesmas dan klinik, melainkan juga harus dilakukan oleh kader kesehatan di desa (Sunarti, 2019).

Kader kesehatan desa adalah lakilaki/wanita yang dipilih oleh masyarakat dan ditetapkan dalam SK kepala desa yang dilatih untuk menangani masalah-masalah kesehatan perseorangan maupun masyarakat (Syafrudin dkk, 2009). Kader kesehatan desa bekerja secara sukarela dan pada umumnya merupakan warga yang tinggal di wilayah kerja kader tersebut. Menjadi kader kesehatan desa tentu sangat banyak tantangannya, seperti tidak memiliki pengetahuan dasar pelayanan terhadap masyarakat, direndahkan ataupun dianggap galak. Menghadapi tantangan tersebut, seorang kader harus bersikap profesional dan harus tetap memberikan pelayanan yang prima, dimana harus dapat memisahkan tugas yang diemban dan perasaan emosional pribadi.

Berdasarkan data di lapangan menunjukkan bahwa pengetahuan dan keterampilan kader dalam melaksanakan tugas masih jauh dari harapan. Hal ini dilihat dari pelaksanaan kegiatan posyandu yang monoton dan tidak berkembang yang nantinya akan berdampak terhadap pelaksanaan program desa siaga. Selama ini, kader posyandu lebih sering menjadi pelaksana kegiatan saja, bukan pengelola posyandu. Menjadi kader posyandu artinya bukan hanya melaksanakan kegiatan posyandu saja, tetapi juga merencanakan kegiatan dan mengaturnya karena merekalah yang paling memahami kondisi kebutuhan masyarakat di wilayahnya (Dirjen Pemberdayaan Masyarakat dan Desa, 2011). Namun, pada kenyataannya banyak kader posyandu yang tidak aktif lagi dan/atau sangat kurang jumlahnya. Selain itu, pengetahuan, sikap dan keterampilan kader posyandu masih kurang, bahkan ada yang belum memahami hal-hal baru berkaitan dengan kegiatan posyandu, perkembangan keadaan dan kebijakan-kebijakan baru yang berkaitan dengan pengelolaan posyandu (Sinambela, 2006).

Sehubungan dengan kondisi di atas, dirasa perlu pelatihan pembentukan budaya pelayanan prima pada kader kesehatan. Penyelenggaraan pengabmas berupaya memberikan peningkatan pengetahuan dan pembentukan budaya pelayanan prima kepada kader kesehatan. Pembentukan pelayanan budaya prima pada kader kesehatan yang dilaksanakan secara virtual/daring merupakan kegiatan dalam rangka mempersiapkan kader kesehatan agar mau dan mampu berperan serta dalam mengembangkan program kesehatan di desanya. 
Sasaran pengabmas yaitu kader kesehatan, dimana setiap RW terdapat 1 orang kader dan di Kelurahan Jabungan terdapat 30 RW dengan total 30 orang kader kesehatan.

Luaran pengabdian masyarakat tentang Pembentukan Budaya Pelayanan Prima pada Kader Kesehatan di Kelurahan Jabungan Banyumanik Kota Semarang berupa peningkatan pemahaman dan keterampilan masyarakat, sertifikat dan Buku Saku Pelayanan Prima Bagi Kader Kesehatan Desa serta hasil pengabmas dijurnalkan di jurnal Pengabmas.

\section{METODE}

Kegiatan pengabdian kepada masyarakat ini terdiri dari beberapa tahap kegiatan yang meliputi tahap perencanaan, pelaksanaan dan evaluasi. Tahap perencanaan meliputi kegiatan persiapan melalui koordinasi dengan pihak Kelurahan Jabungan untuk membahas rencana kegiatan pelatihan, menetapkan sasaran dan mengidentifikasi jumlah peserta pelatihan, menyusun jadwal kegiatan, menyiapkan materi dan narasumber serta sarana dan prasarana kegiatan berupa link zoom meeting, kuota dan perangkat komputer/laptop.

Kegiatan pengabmas dilaksanakan melalui pelatihan pelayanan prima dengan metode ceramah dan demonstrasi secara daring, memberikan kesempatan kepada kader kesehatan untuk mencoba mempraktikkan contoh pelayanan prima sesuai arahan narasumber. Peserta pelatihan pada akhir kegiatan akan memperoleh pedoman pelayanan prima.

Evaluasi kegiatan dilakukan sebelum dan setelah pemberian materi serta pendampingan untuk mengetahui penerapan pelatihan pelayanan prima. Penyusunan Rencana Tindak Lanjut (RTL) pelaksanaan pelatihan pelayanan prima pada kader kesehatan di Kelurahan Jabungan Banyumanik Kota Semarang.

\section{HASIL DAN PEMBAHASAN}

Kegiatan pengabmas diawali dengan melakukan penjajakan lokasi dan perizinan di Kelurahan Jabungan. Penjajakan lokasi dimaksudkan untuk mendapatkan perizinan dari pemangku wilayah serta informasi tentang berbagai permasalahan kesehatan yang terdapat di lokasi. Berdasarkan informasi tersebut, pengabdi melakukan koordinasi dengan koordinator kader kesehatan untuk menentukan kepesertaan dan waktu penyelenggaraan kegiatan. Kegiatan selanjutnya yaitu menghubungi narasumber dan mengajukan permohonan sebagai narasumber. Koordinasi kegiatan dan penyampaian informasi dari pengabdi dan peserta dilakukan melalui media whatsapp group (WAG). Pemilihan WAG selain sebagai media komunikasi untuk mempersiapkan kegiatan, WAG familiar penggunaannya bagi peserta/kader sehingga meminimalisir hambatan pada saat pelaksanaan kegiatan.

Pengabdi mempersiapkan sarana prasarana dan menyiapkan kelengkapan kegiatan yaitu jadwal kegiatan, link zoom, saftar hadir peserta dan alat evaluasi beserta link yang digunakan pada saat kegiatan.

Pelaksanaan kegiatan pengabmas dilakukan secara full daring. Hal tersebut dimaksudkan untuk mematuhi kebijakan Program Pembatasan Kesehatan Masyarakat (PPKM) di wilayah Kota Semarang serta menghindari adanya penyebaran Covid-19 diantara kader kesehatan. Kegiatan ini direncanakan diikuti oleh 30 kader, namun karena sebagian kader masih berada di tempat kerja dan/atau mengikuti kegiatan lain maka yang dapat bergabung sebanyak 18 kader.

Kegiatan pengabmas dilaksanakan pada taggal 8 Agustus 2021 mulai pukul 15.00 WIB sampai dengan pukul 18.00 WIB. Media yang digunakan pada kegiatan tersebut yaitu zoom meeting dengan link https://zoom.us/j/99374870394?pwd=Qmt6VE 16T3JBRFgyeDE1VE44MmY4UT09.

Kegiatan pengabmas ini menghadirkan tiga orang narasumber. Narasumber pertama Sri Lestari SKM., M.Kes, narasumber kedua Adhani Windari, SKM, M.Kes, dan narasumber ketiga Elise Garmelia, S.KM, S.Sos, M.Si, Ph.D. Materi yang disampaikan oleh narasumber pertama yaitu "Penerapan $5 S$ dalam Pelayanan Kader Kesehatan". Materi tentang "Konsep Kerja 5R dalam Pelayanan Kesehatan" disampaikan oleh narasumber kedua, sedangkan narasumber ketiga menyampaikan materi "Komunikasi Efektif Kader".

Penyampaian materi dilaksanakan secara panel dan setelah selesai pemaparan dilakukan diskusi dan tanya jawab. Kader menyambut kegiatan tanya jawab dengan antusias dan menanyakan masalah yang sering dihadapi ketika memberikan layanan. Pengabdi sangat mengapresiasi semangat kader kesehatan dalam mengikuti pengabmas. Bentuk apresiasi tersebut diberikan dalam bentuk pemberian serifikat serta dipilih tiga peserta teraktif untuk diberikan penghargaan berupa cinderamata.

Kegiatan pengabdian kepada masyarakat perlu dilakukan evaluasi untuk mengetahui kemanfaatan kegiatan bagi masyarakat. Kegiatan pengabdian kepada 
masyarakat ini dilakukan dua jenis evaluasi, yaitu evaluasi peningkatan pengetahuan kader dan evaluasi kegiatan pengabmas. Evaluasi disampaikan kepada kader kesehatan menggunakan google form. Hasil evaluasi tersebut secara rinci sebagai berikut:

\section{Evaluasi Peningkatan Pemahaman}

Pemahaman kader kesehatan terhadap pelayanan prima sebelum diberikan materi dilakukan evaluasi awal/pretest. Evaluasi awal dimaksud untuk mengetahui pengetahuan kader terhadap pelayanan prima. Di akhir kegiatan, kader diberikan posttest. Posttest dimaksudkan untuk mengetahui efektifitas kegiatan dan mengetahui tingkat penyerapan materi yang disampaikan narasumber oleh kader.

Materi evaluasi meliputi peran kader, pengertian pelayanan prima, tujuan pelayanan prima serta beberapa prinsip dan teknis pelayanan. Hasl evaluasi dan peningkatan pemahaman kader secara rinci dapat dilihat dalam tabel 1 di bawah ini:

Tabel 1. Hasil Pretest dan Posttest

Pengetahuan Kader Mengenai Pelayanan

\begin{tabular}{|c|c|c|c|c|}
\hline \multirow[b]{2}{*}{ No } & \multirow{2}{*}{$\begin{array}{c}\text { Materi } \\
\text { Evaluasi }\end{array}$} & \multicolumn{2}{|c|}{ Hasil Tes (\%) } & \multirow{2}{*}{$\begin{array}{l}\text { Peni- } \\
\text { ngkat- } \\
\text { an } \\
(\%)\end{array}$} \\
\hline & & Pre & Post & \\
\hline 1. & $\begin{array}{l}\text { Peran Kader } \\
\text { kesehatan di } \\
\text { masyarakat } \\
\text { adalah.... }\end{array}$ & 87,5 & 100 & 12,5 \\
\hline 2. & $\begin{array}{l}\text { Pelayanan } \\
\text { prima } \\
\text { adalah.... }\end{array}$ & 31,25 & 100 & 68,75 \\
\hline 3. & $\begin{array}{l}\text { Dalam bidang } \\
\text { kesehatan, } \\
\text { siapakah yang } \\
\text { harus } \\
\text { memberikan } \\
\text { pelayanan } \\
\text { prima? }\end{array}$ & 31,25 & 100 & 68,75 \\
\hline 4. & $\begin{array}{l}\text { Tujuan } \\
\text { pelaksanaan } \\
\text { pelayanan } \\
\text { prima } \\
\text { adalah.... }\end{array}$ & 31,25 & 100 & 68,75 \\
\hline 5. & $\begin{array}{l}\text { Penilaian } \\
\text { pelanggan } \\
\text { terhadap } \\
\text { petugas } \\
\text { pemberi } \\
\text { layanan antara } \\
\text { lain } \\
\text { berdasarkan } \\
\text { reliability, } \\
\text { artinya.... }\end{array}$ & 31,25 & 87,5 & 56,25 \\
\hline 6. & $\begin{array}{l}\text { Perilaku yang } \\
\text { memberikan } \\
\text { kesan positif } \\
\text { bertatap muka }\end{array}$ & 31,25 & 87,5 & 56,25 \\
\hline
\end{tabular}

\begin{tabular}{|c|c|c|c|c|}
\hline & $\begin{array}{l}\text { pada customer } \\
\text { adalah } \\
\text { sebagai } \\
\text { berikut.... }\end{array}$ & & & \\
\hline 7. & $\begin{array}{l}\text { Prinsip } \\
\text { komunikasi } \\
\text { dalam layanan } \\
\text { dimana } \\
\text { pemberi } \\
\text { layanan harus } \\
\text { dapat } \\
\text { memberikan } \\
\text { yang jelas, apa } \\
\text { adanya namun } \\
\text { tetap santun, } \\
\text { disebut.... }\end{array}$ & 37,5 & 81,25 & 43,75 \\
\hline 8 & $\begin{array}{l}\text { Di bawah ini } \\
\text { merupakan } \\
\text { sikap agresif } \\
\text { yang tidak } \\
\text { boleh dimiliki } \\
\text { oleh pemberi } \\
\text { layanan.... }\end{array}$ & 37,5 & 87,5 & 50 \\
\hline 9. & $\begin{array}{l}\text { Pelayanan } \\
\text { yang } \\
\text { menerapkan } \\
\text { konsep sikap } \\
\text { (attitude) } \\
\text { adalah } \\
\text { sebagai } \\
\text { berikut... }\end{array}$ & 43,75 & 87,5 & 43,75 \\
\hline 10. & $\begin{array}{l}\text { Setiap pemberi } \\
\text { layanan harus } \\
\text { memberikan } \\
\text { salam kepada } \\
\text { pelanggannya, } \\
\text { maksudnya } \\
\text { yaitu.... }\end{array}$ & 37,5 & 100 & 62,5 \\
\hline
\end{tabular}

Pengetahuan kader terhadap peran diemban secara umum sudah baik. Meskipun pada pretest baru $87,5 \%$ menjawab dengan benar, namun pada posttest $100 \%$ menjawab dengan benar. Materi budaya pelayanan prima yang disampaikan pada kegiatan pengabmas ini bagai memberikan penyegaran terhadap kader kesehatan. Pemberian contoh-contoh nyata yang disampaikan narasumber dapat mengingatkan kembali tentang peran, tugas, dan fungsi seorang kader kesehatan desa. Kenyataan tersebut dapat diungkap dengan adanya evaluasi pretest dan posttest, dimana terjadi peningkatan pengetahuan terhadap peran kader kesehatan sebesar $12,5 \%$.

Pengetahuan kader terhadap pengertian pelayanan prima terjadi peningkatan sebanyak $68,75 \%$ dari nilai pretest 31,25. Pemaparan materi yang disampaikan oleh narasumber mampu meningkatkan pengetahuan kader sehingga pada hasil posttest mencapai $100 \%$ jawaban benar. Suatu kemajuan pengetahuan yang bagus dan membuktikan bahwa materi yang disampaikan 
oleh narasumber dapat diterima dengan baik oleh kader.

Kader yang telah mengetahui tujuan pelayanan prima sebelum dilaksanakan pemaparan materi sebanyak 31,25\%. Pengetahuan kader meningkat sebanyak $68,75 \%$ setelah diberikan materi tentang budaya pelayanan prima. Peningkatan yang sangat signifikan, sehingga di akhir kegiatan $100 \%$ kader telah mengetahui tujuan pelayanan prima. Seiring peningkatan pengetahuan diharapkan nantinya kader kesehatan dapat memahami serta menerapkan budaya tersebut saat memberikan layanan.

Penilaian pelanggan berdasarkan aspek reliability yaitu menilai pemberi layanan yang handal/mampu menjalankan tugas. Pada saat pretest kader yang mengetahui hal ini sebanyak $31,25 \%$. Namun, pada saat posttest meningkat menjadi $87,5 \%$. Peningkatan pengeahuan kader sebanyak 56,25\% merupakan peningkatan yang bagus meskipun penyampaiannya secara daring.

Seorang kader sebaiknya dalam memberikan pelayanan dapat memberikan kesan positif terhadap pelanggannya. Salah satu kesan tersebut dapat diketahui pada saat berbicara dengan pelanggan menerapkan teknik "eye level" atau ketinggian pandangan disesuaikan dengan pandangan pelanggan. Pengetahuan tentang prinsip komunikasi ini awalnya baru diketahui oleh $31,25 \%$ kader. Namun, setelah selesai pemaparan, pengetahuan kader meningkat menjadi $87,5 \%$. Dengan demikian, penyampaian materi tentang budaya pelayanan prima, khususnya teknik komunikasi terhadap pelanggan terjadi peningkatan sebanyak $56,25 \%$.

Prinsip komunikasi dalam layanan dimana pemberi layanan memberikan informasi yang jelas apa adanya dan tetap santun telah diketahui dari awal oleh $37,5 \%$ kader. Pengetahuan tersebut meningkat hingga $81,25 \%$ setelah narasumber memberikan pencerahan tentang prinsip-prinsip komunikasi efektif. Peningkatan pengetahuan terhadap prinsip komunikasi mengalami peningkatan sebanyak $43,75 \%$. Peningkatan ini tak lepas dari kemampuan narasumber dalam memberikan contoh kasus yang sesuai dengan kenyataan di masyarakat.

Sebanyak $37,5 \%$ kader telah memiliki dasar pengetahuan tentang sikap pemberi layanan. Kenyataan tersebut dapat ditunjukkan pada hasil pretest kader dapat memberikan contoh sikap agresif yang tidak boleh dimiliki oleh pemberi layanan. Pemberian tambahan pengetahuan yang disampaikan oleh narasumber telah meningkatkan pengetahuan kader menjadi $87,5 \%$ yang dapat diketahui dari hasil posttest. Peningkatan pengetahuan sebanyak $50 \%$ tentang sikap-sikap yang tidak boleh dimiliki oleh kader diharapkan nantinya dapat meningkatkan mutu layanan yang dilakukannya.

Pelayanan yang diharapkan tertanam pada diri para kader kesehatan adalah sikap yang baik, ramah, penuh simpatik dan mempunyai rasa memiliki yang tinggi terhadap tugas. Kader Kesehatan Kelurahan Jabungan sebanyak 43,75\% telah mengetahui hal tersebut. Dilaksanakannya pengabmas ini memberikan semacam penyegaran pengetahuan pada kader, sehingga pada akhir kegiatan terjadi peningkatan pengetahuan sebanyak $43,75 \%$. Peningkatan tersebut dapat disimpulkan dengan melihat hasil posttest pada akhir kegiatan sebanyak 87,5\% kader menjawab pertanyaan dengan benar. Berbekal pengetahuan tersebut nantinya kader kesehatan dapat memberikan layanan lebih baik dari sebelumnya.

Kader kesehatan Kelurahan Jabungan sebanyak $37,5 \%$ telah memahami keharusan pemberi layanan memberikan salam kepada pelanggannya. Pemahaman kader mengalami peningkatan sebanyak $62,5 \%$ pada akhir kegiatan setelah mendengarkan pemaparan dari narasumber tentang pelayanan berbasis $5 S$ (senyum, salam, sapa, sopan dan santun). Hasil evaluasi pada posttest seluruh kader $(100 \%)$ menjawab dengan benar pertanyaan tentang maksud salam.

Secara keseluruhan, penyampaian materi tentang budaya pelayanan prima pada kader kesehatan Kelurahan Jabungan telah meningkatkan pengetahuan sebanyak 53,13\%. Hasil pretest rata-rata diperoleh $40 \%$ jawaban benar dan nilai posttest diperoleh rata-rata nilai sebanyak 93,13\% menjawab dengan benar. Suatu peningkatan pengetahuan yang sangat baik bila dilihat berdasarkan hasil evaluasi sebelum dan sesudah kegiatan. Pengetahuan kader yang telah meningkat tersebut perlu dikaji kembali kemanfaatannya dalam pelaksanaan peran dan fungsinya di masyarakat. Berkaitan dengan hal tersebut, diperlukan evaluasi tentang kegiatan pengabmas penerapan budaya pelayanan prima bagi kader kesehatan Kelurahan Jabungan.

\section{Evaluasi Kegiatan Pengabdian Kepada Masyarakat}

Evaluasi kegiatan pengabdian kepada masyarakat dimaksudkan untuk menilai kejelasan materi, kemanfaatan kegiatan, kesesuaian kegiatan dengan kebutuhan kader serta penguasaan materi narasumber. Penilaian diberikan oleh kader melalui google 
form setelah selesai kegiatan diskusi dan tanya jawab.

Penilaian dinyatakan dalam suatu pernyataan/persetujuan kader terhadap kegiatan pengabmas. Pernyataan tersebut memiliki rentang 1 sampai dengan 5 . Rentang pernyataan tersebut menunjukkan pernyataan sangat kurang setuju (1), kurang setuju (2), cukup setuju (3), setuju (4) dan sangat setuju (5). Hasil evaluasi kegiatan secara rinci sebagai berikut:

Tabel 2. Hasil Evaluasi Kegiatan Pengabdian Kepada Masyarakat

\begin{tabular}{clc}
\hline No & \multicolumn{1}{c}{ Materi Evaluasi } & $\begin{array}{c}\text { Hasil } \\
\text { Evaluasi }\end{array}$ \\
\hline 1 & $\begin{array}{l}\text { Materi yang disampaikan } \\
\text { narasumber disampaikan } \\
\text { secara jelas }\end{array}$ & 4,5 \\
\hline 2 & $\begin{array}{l}\text { Penjelasan yang diberikan } \\
\text { narasumber } \\
\text { dipahami }\end{array}$ & mudah \\
\hline 3 & $\begin{array}{l}\text { Materi yang diberikan } \\
\text { narasumber } \\
\text { diterapkan dalam kegiatan } \\
\text { pelayanan }\end{array}$ & 4,6 \\
\hline 4 & $\begin{array}{l}\text { Materi yang diberikan } \\
\text { narasumber bermanfaat }\end{array}$ & 4,7 \\
\hline 5 & $\begin{array}{l}\text { Narasumber menguasai } \\
\text { materi yang dipaparkan }\end{array}$ & 4,5 \\
\hline 6 & $\begin{array}{l}\text { Kegiatan pengabmas sesuai } \\
\text { kebutuhan Kader Kesehatan }\end{array}$ & 4,6 \\
\hline 7 & $\begin{array}{l}\text { Kegiatan pengabmas } \\
\text { meningkatkan pengetahuan } \\
\text { Kader Kesehatan }\end{array}$ & 4,9 \\
\hline
\end{tabular}

Berdasarkan tabel di atas dapat disimpulkan bahwa kader kesehatan Kelurahan Jabungan menilai bahwa materi disampaikan jelas. Hasil evaluasi kegiatan rata-rata sebesar 4,5 menunjukkan pernyataan kader terhadap kejelasan materi yang disampaikan oleh narasumber.

Kegiatan pengabmas yang dilaksanakan secara daring terkadang menemui hambatan dimana jaringan putusnyambung. Menghadapi kenyataan ini, pengabdi dan narasumber tak bosan-bosannya menanyakan apakah yang telah disampaikan dapat diterima dengan baik atau putus-putus. Bila kader menjawab suara kurang lancar, maka narasumber akan mengulangi penjelasannya.

Penjelasan yang disampaikan narasumber dibuat semirip mungkin dengan kenyataan yang dihadapi kader, sehingga mudah dipahami. Berdasarkan kesan dan pesan yang disampaikan kader, contoh-contoh yang diberikan oleh narasumber dapat ditiru dan sangat membantu menghadapi hal-hal yang sering terjadi di masyarakat. Hasil evaluasi kegiatan mengenai kemudahan materi untuk dipahami mendapatkan nilai rata rata 4,6 yang berarti kader menyatakan persetujuannya mengenai penjelasan narasumber yang mudah dipahami.

Salah satu luaran yang ingin diraih melalui pengabmas dengan memberikan materi penerapan budaya pelayanan prima adalah peningkatan pemahaman dan keterampilan masyarakat, khususnya kader. Berkaitan dengan hal tersebut, pemberian contoh diambil dari kasus-kasus yang dihadapi kader, sehingga kader dengan mudah menerapkan materi yang sudah diberikan. Hasil evaluasi kegiatan pengabmas mendaptkan nilai rata-rata 4,7 , berarti kader menilai materi yang diberikan narasumber mudah diterapkan. Beberapa kader menyampaikan bahwa pengabmas yang dilaksanakan sangat berkesan serta menyarankan untuk dilaksanakan secara luring. Kader Kesehatan Kelurahan Jabungan menilai kemanfaatan materi yang diberikan dengan hasil evaluasi rata-rata 4,7. Kesan yang disampaikan kader kepada pengabdi yaitu pemaparan materi sangat bermanfaat. Kader menyatakan ilmu yang diperolehnya dapat diterapkan dalam rumah tangga dan mereka menginginkan untuk dilakukan praktik secara langsung, namun terkendala PPKM sehingga saat ini belum dapat terlaksana.

Penguasaan narasumber dalam memaparkan materi hasil evaluasinya 4,5 . Dengan demikian, kader menyatakan narasumber menguasai materi dengan baik. Penguasaan materi oleh narasumber membuat suasana diskusi tentang permasalahan yang dihadapi kader yang berkaitan dengan pelayanan prima menjadi hidup. Secara antusias, kader-kader menanyakan beberapa kendala yang dihadapinya dan mereka terpuaskan dengan jawaban yang disampaikan narasumber.

Peran sebagai kader kesehatan dituntut memiliki kemampuan dalam melakukan komunikasi efektif. Penyampaian materi komunikasi efektif dalam pengabmas yang bertujuan meningkatkan kemampuan kader menerapkan pelayanan prima. Penilaian kader terhadap kesesuaian materi pengabmas dengan kebutuhan dalam melaksanakan tugasnya mendapat poin 4,6, dimana kader menyatakan kesesuaian materi pengabmas dengan kebutuhan dalam pelaksanaan tugasnya.

Kegiatan pengabmas ini dinilai meningkatkan pengetahuan kader kesehatan. Poin evaluasi menunjukkan angka 4,9 yang berarti kader kesehatan menyatakan materi pengabmas tentang penerapan budaya pelayanan prima meningkatkan pengetahuan kader kesehatan. 
Penilaian dan sambutan kader terhadap kegiatan pengabmas sangat baik, tapi bukan berarti pelaksanaan kegiatan tidak ditemui kendala. Kendala utama kegiatan pelatihan pelayanan prima yang dilaksanakan secara daring yaitu sering terjadi gangguan jaringan sehingga penyampaian narasumber tidak diterima secara utuh/putus-putus. Keadaan ini disadari oleh semua pihak, sehingga narasumber sering menanyakan yang telah disampaikan untuk memastikan kader dapat menerima materi tersebut dengan baik. Pengabdi juga memberi waktu untuk melakukan tanya jawab serta diskusi tentang masalah yang dihadapi kader dalam memberikan layanan kepada masyarakat. Kesan dan pesan kader terhadap kegiatan pengabmas selain sangat bermanfaat, mereka mengharapkan pada kesempatan lain dapat dilaksanakan kegiatan yang sama secara luring.

\section{SIMPULAN DAN SARAN}

Pengabdian kepada masyarakat tentang Pembentukan Budaya Pelayanan Prima pada Kader Kesehatan di Kelurahan Jabungan Banyumanik Kota Semarang merupakan salah satu realisasi Tri Dharma Perguruan Tinggi.

Pengabdian kepada masyarakat berupa pelatihan pelayanan prima bagi kader kesehatan di Kelurahan Jabungan Banyumanik Kota Semarang. Pelatihan terhadap 18 kader kesehatan tersebut dilaksanakan secara daring melalui media zoom. Hasil pelatihan tentang budaya pelayanan prima pada kader kesehatan Kelurahan Jabungan telah meningkatkan pengetahuan sebanyak 53,13\%.

Kegiatan Pengabmas tentang budaya pelayanan prima pada kader kesehatan Kelurahan Jabungan merupakan bentuk sumbangsih Jurusan Rekam Medis dan Informasi Kesehatan Poltekkes Kemenkes Semarang terhadap desa binaan yang telah menjadi mitra dalam penyelenggaraan pendidikan.

Pelaksanaan pengabmas berbentuk pelatihan yang dilaksanakan secara daring banyak terkendala masalah jaringan, sebaiknya dapat dilaksanakan pelatihan secara luring.

Pembentukan budaya pelayanan prima bagi kader kesehatan diperlukan pemantauan serta penyegaran kembali dalam penerapan hasil pelatihan pelayanan prima bagi kader kesehatan di desa binaan, sehingga diperlukan tindak lanjut kegiatan pengabmas.

\section{UCAPAN TERIMAKASIH}

Pengabdi menyampaikan terima kasih kepada kepala Kelurahan Jabungan beserta perangkat yang telah memberikan izin dan kemudahan penyelenggaraan kegiatan pengabmas tentang Pembentukan Budaya Pelayanan Prima pada Kader Kesehatan Kelurahan Jabungan.

\section{DAFTAR RUJUKAN}

Barata, A. A. (2003). Dasar-Dasar Pelayanan Prima. PT Elex Media Komputindo.

Dirjen Pemberdayaan Masyarakat dan Desa. (2011). Pedoman Umum Pengelolaan Posyandu. Badan Pemberdayaan Masyarakat Kabupaten Blitar.

Dwiyanto, A. (2005). Mewujudkan Good Governance Melalui Pelayanan Publik. Gadjah Mada University Press.

Lukman, S. (2000). Manajemen Kualitas Pelayanan. STIA LAN Press.

Rumah Sakit Umum dr. Moedjito Dwidjosiswojo. (2020). Pelayanan Prima (Service Excellent) di Rumah Sakit Jawa Timur.

Sinambela, L. (2006). Reformasi Pelayanan Publik, Teori, Kebijakan dan Implementasi. Bumi Aksara.

Sunarti, S. U. (2019). PERAN KADER KESEHATAN DALAM PELAYANAN POSYANDU UPTD PUSKESMAS KECAMATAN SANANWETAN KOTA BLITAR. Jurnal Keperawatan Malang, 3(2), 94-100. https://doi.org/10.36916/jkm.v3i2.63

Syafrudin dkk. (2009). Kebidanan Komunitas. EGC. 